\title{
In memoriam: Billy Fenlon
}

\author{
P. Fleming ${ }^{1}$ D. Daly ${ }^{2}$
}

Published online: 13 November 2017

(C) European Academy of Paediatric Dentistry 2017

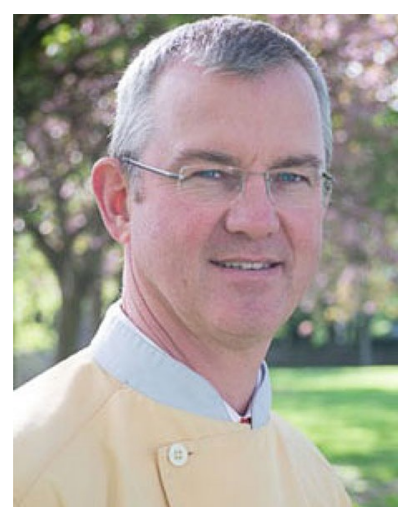

Dr. Billy Fenlon passed away earlier this year following a short illness. Billy studied dentistry at Trinity College Dublin, qualifying first in his year with a BDentSc (Hons) degree in 1984. He worked as a house officer in the Dublin Dental Hospital and in general dental practice and developed a keen interest in treating children.

Billy was a leader and was the first Irish dentist to undertake the 3-year postgraduate programme in paediatric dentistry at Leeds University that had been recently developed by Professor Martin Curzon. In Leeds, Billy forged life-long friendships with an emerging group of young paediatric dentists, many of whom would go on to lead the specialty. He graduated MDentSc (Hons) from Leeds University in 1990 and subsequently obtained fellowships from the Royal College of Dentists of Canada and from the Royal College of Surgeons in Ireland.

\footnotetext{
P. Fleming

paddy.fleming@dental.tcd.ie

1 Dublin, Ireland

2 Galway, Ireland
}

On his return to Ireland, Billy developed a specialist practice in paediatric dentistry in Dublin, "Billy the Kid's Dentist", where he provided superb dental care for children. He also gave of his time to provide dental care for severely medically compromised children in the expanding dental department at Our Lady's Children's Hospital in Dublin.

As the EAPD Council member for Ireland, Billy successfully bid to host the Academy's 6th Congress in Dublin and organised a most successful scientific and social event in Trinity College Dublin in June 2002. During the congress it became clear that many delegates were keen to follow their countries' progress in the World Cup football finals that were taking place in Korea and Japan at that time. Billy responded to this need and made special arrangements for such delegates to view their countries' matches 'live' while attending the congress!

Colleagues from distant lands, including Australia, had attended the EAPD Congress in Dublin and subsequently Billy visited IAPD congresses in Sydney and in Hong Kong, where he was an invited speaker. Billy's visit to Sydney in 2005 was memorable for the respect shown to him by so many colleagues, his visit to the Department of Paediatric Dentistry at Westmead Hospital Sydney, climbing the Sydney Bridge and his day trip to attend the Melbourne Cup horse race.

Billy met his future wife and soul mate, Celine, when they were undergraduate dental students and they had a loving and enduring relationship. Their daughter Hannah and sons Robert and Hugh completed a wonderful family and Billy's enthusiasm for sport no doubt had a part to play in their active participation, including the boys' involvement in Gaelic football, hurling and school rugby.

Billy was the most generous of friends. He was happy to share his extensive knowledge with dental colleagues, and many of us benefitted greatly from his wise advice. He 
had a wonderful sense of humour and joie de vivre. He was great company, and all who knew him appreciated his wit and kind humour.

Billy had an encyclopedic knowledge of sport with his specialty being horse racing. At one stage he was a joint owner of a horse and had his own racing colours. He loved to attend race meetings and this involved an annual visit to Cheltenham, which afforded him an opportunity to meet up with family there.

Billy is sadly missed. Our thoughts and prayers go out to Celine, Hannah, Robert and Hugh and to all other family members and close friends. 